\title{
DETERMINATION OF STRAINS OF Helicobacter pylori AND OF POLYMORPHISM IN THE INTERLEUKIN-8 GENE IN PATIENTS WITH STOMACH CANCER
}

\author{
Ruth Maria Dias Ferreira VINAGRE' ${ }^{1}$, Tereza Cristina de Oliveira CORVELO², \\ Vanda Catão ARNAUD ${ }^{3}$, Ana Claudia Klautau LEITE ${ }^{4}$, \\ Katarine Antonia dos Santos BARILE² and Luisa Caricio MARTINS ${ }^{5}$
}

\begin{abstract}
Context - Gastric neoplasia is the second most common cause of death by cancer in the world and $H$. pylori is classified as a type I human carcinogen by the World Health Organization. However, despite the high prevalence of infection by $H$. pylori around the world, less than $3 \%$ of individuals carrying the bacteria develop gastric neoplasias. Such a fact indicates that evolution towards malignancy may be associated with bacterial factors in the host and the environment. Objectives - To investigate the association between polymorphism in the region promoting the IL-8 (-251) gene and the H. pylori genotype, based on the vacA alleles and the presence of the cagA gene, using clinical and histopathological data. Methods - In a prospective study, a total of 102 patients with stomach cancer and 103 healthy volunteers were analysed. Polymorphism in interleukin $8(-251)$ was determined by the PCRrestriction fragment length polymorphism reaction and sequencing. PCR was used for genotyping the vacA alleles and the cagA in the bacterial strains PCR. Gastric biopsies were histologically assessed. Results - The H. pylori serology was positive for 101 (99\%) of all patients analysed, and $98(97 \%)$ of them were colonized by only one strain. In patients with monoinfection, $82(84 \%)$ of the bacterial strains observed had the $s 1 \mathrm{~b} / \mathrm{ml}$ genotype. The cagA gene was detected in 74 (73\%) of patients infected by $H$. pylori. The presence of the $c a g \mathrm{~A}$ gene was demonstrated as associated with the presence of the $s 1 \mathrm{~b} / \mathrm{ml}$ genotype of the vacA gene $(P=0.002)$. As for polymorphism in the interleukin $8(-251)$ gene we observed that the AA $(P=0.026)$ and AT $(P=0.005)$ genotypes were most frequent in the group of patients with gastric adenocarcinoma. By comparing the different types of isolated bacterial strains with the interleukin -8 (-251) and the histopathological data we observed that carriers of the A allele (AT and AA) infected by virulent strains $(\mathrm{mls} 1 \mathrm{cag} \mathrm{A}+)$ demonstrated a greater risk of presenting a degree of inflammation $(\mathrm{OR}=24.75 \mathrm{CI} 95 \% 2.29-267.20 P=0.004)$ and increased neutrophilic activity $(\mathrm{OR}=28.71 \mathrm{CI} 95 \% 2.62-314 P=0.002)$ in the gastric mucosa. Conclusion - Our results demonstrate that the interaction between polymorphism in the interleukin -8 (-251) gene, particularly with carriers of the A allele and the infecting type of H. pylori strain ( $1 \mathrm{ml}$ cagA positive) performs an important function in development of gastric adenocarcinoma.
\end{abstract}

HEADINGS - Helicobacter pylori. Stomach neoplasms. Polymorphism, genetic. Interleukin-8.

\section{INTRODUCTION}

Infection by $H$. pylori is considered one of the most important factors in the pathogenesis of various gastrointestinal diseases, such as: chronic gastritis, atrophic gastritis, peptic ulcers, carcinoma and gastric lymphoma ${ }^{(14,28)}$. However, the majority of infected patients remain asymptomatic carriers throughout their lives and only $20 \%$ may evolve towards a more serious gastrointestinal disease during their lives ${ }^{(14,}$ ${ }^{20)}$, with fewer than 3\% being observed developing stomach cancer ${ }^{(10)}$. The great variability in clinical manifestations of $H$. pylori infection is associated to several factors, including: bacterial virulence factors, environmental factors and genetic factors of hosts, or a combination of both ${ }^{(2,8)}$.

Especially important among the bacterial virulence factors are cytotoxin vacA and cagA, which are associated with bacterial pathenogenicity. Studies conducted in several countries have shown that vacA-type s1m1 and cagA-positive $H$. pylori strains are associated with severe $H$. pylori-induced peptic ulcer disease ${ }^{(3,}$ 11, 24). Recent publications have also uncovered this association in Brazil $^{(1,7)}$.

However, bacterial virulence factors alone are not sufficient for determining clinical evolution of the

Institution: Nucleus of Tropical Medicine, Federal University of Pará, Belém, PA, Brasil.

1 Department of Clinical Medicine, Ophir Loyola Hospital, ${ }^{2}$ Immunogenetics Laboratory, Federal University of Pará, ${ }^{3}$ Pathology Laboratory, Ophir Loyola Hospital,

${ }^{4}$ Department of Endoscopy, Ophir Loyola Hospital, ${ }^{5}$ Laboratory for Clinical Pathology of Tropical Diseases, Federal University of Pará, Belém, PA, Brasil.

Correspondence: Dr. Luisa Caricio Martins - Travessa Mauriti, 3269 - apt. 704 B - Bairro Marco - 66095-360 - Belém, PA, Brasil. E-mail: caricio@ufpa.br 
infection, given that virulent strains are frequent in both patients with peptic ulcers and those with gastric carcinoma ${ }^{(18,}$ 32). Other factors in the host, especially those that regulate the immunological and inflammatory response, may also contribute to progression towards neoplasia ${ }^{(8,9)}$.

Genetic polymorphisms, particularly those occurring in the region that promotes the genes that codify inflammatory cytotoxins have been associated to an increase in the synthesis of those interleukins and have emerged as important determinants of susceptibility to cancer ${ }^{(12,25)}$.

$H$. pylori indirectly stimulates activation of a cascade of cytotoxins responsible for development of the inflammatory process. Infection by $H$. pylori, induces the gastric epithelial cells to secrete interleukins with chemotactic properties for neutrophils and mononuclear cells such as interleukin (IL)-8, IL-6 and IL-1, leading to a proliferative response, with a dense infiltrate of neutrophils and plasmatic cells in the gastric mucosa, leading to active chronic gastritis ${ }^{(17)}$.

Some studies have described the gene that codifies IL8 as having the polymorphism of an A/T base pair in the promoting region $(-251)$ that is associated with an increase in synthesis of that interleukin by gastric epithelial cells ${ }^{(29}$, ${ }^{33)}$. It is thus associated with an elevated risk of developing stomach cancer ${ }^{(25,29,33)}$.

In Belém, PA, Brazil, a high rate of prevalence of infection by the bacteria has been described in adult patients with gastric disturbances ${ }^{(22,23)}$. Furthermore, the Northern Region of Brazil has a high frequency of gastric pathologies such as peptic ulcers and gastric adenocarcinoma ${ }^{(5)}$.

\section{METHODS}

\section{Patients and control sample}

Peripheral blood and gastric fragment samples were collected from 102 patients with gastric carcinoma from the state of Pará, at the Endoscopy Service of the Ophir Loyola University Hospital, during the period of September 2007 to September 2008. During endoscopy, four biopsy fragments were taken from the stomach of each patient. Biopsies of the cancer lesion and the adjacent area (perilesion) were obtained from every patient for histological analysis, and two antrum specimens were also analysed using molecular methods. None of the patients had received antimicrobial drugs, H2-receptor antagonists, acid pump inhibitors, nonsteroidal antiinflammatory drugs, or any medication for at least 60 days prior to endoscopy.

For the control sample peripheral blood samples were collected from 103 patients lacking clinical or metabolic diseases and asymptomatic for gastrointestinal disturbances, who were thus not submitted to endoscopic exams. All the individuals included (patients and control) were from the same socioeconomic level and had similar cultural habits, and all were natives of Pará state with the same ethnic background, approximately 50\% Portuguese, $40 \%$ Amerindian, $10 \%$ African $^{(5)}$. The study was approved by the Ethics Committee at Núcleo de Medicina Tropical, Belém,
PA (Protocol 036/2007 - CEP/NMT). All patients gave their informed consent to participate in the experiment.

\section{Detection of infection by $\boldsymbol{H}$. pylori}

In the control group, presence of the specific $H$. pylori $\mathrm{IgG}$ and $c a g \mathrm{~A}$ antibodies was studied in serum samples. To detect specific H. pylori IgG antibodies the commercial HIK anti-H. pylori EIA kit was used (Monobind, Inc, USA), and the Helicobacter P-120 EIA commercial kit, from VIVA Diagnostica, Hürth, Germany was employed for researching anti-cagA antibodies, both being utilized according to the manufacturers' technical descriptions.

\section{DNA isolation}

Total DNA was extracted from frozen gastric biopsy specimens using the following procedure: $10 \mu$ l of proteinase $\mathrm{K}$ and $300 \mu \mathrm{l}$ of lysis buffer ( $200 \mathrm{mM}$ Tris- $\mathrm{HCl}, 25 \mathrm{mM}$ EDTA, $300 \mathrm{mM} \mathrm{NaCl}, 1.2 \%$ sodium dodecyl sulfate) were added to the biopsy specimens. The mixture was incubated at $55^{\circ} \mathrm{C}$ for $12 \mathrm{~h}$. The lysate was extracted with an equal volume of phenol-chloroform, precipitated with isopropanol, and washed with $70 \%$ ethanol. The pellet was dried and suspended in $200 \mu \mathrm{l}$ of sterile distilled water. DNA extracts were stored at $-20^{\circ} \mathrm{C}$.

\section{PCR amplification and detection of amplified DNA products}

One set of primers $(\mathrm{p} 1 \text { and } \mathrm{p} 2)^{(16)}$ that amplifies a gene fragment of $298 \mathrm{bp}$ present in all strains of H. pylori was used to detect bacterial DNA. Only positive samples were used for further study.

Amplification of vacA signal sequences and middle regions was performed by PCR with oligonucleotide primers described by Atherton et al. ${ }^{(3)}$. The strains were initially characterized as being either type $\mathrm{s} 1$ or $\mathrm{s} 2$ and as either type $\mathrm{m} 1$ or $\mathrm{m} 2$. All s1 strain alleles were further characterized as either variant sla or $\mathrm{s} 1 \mathrm{~b}$. The previously described $\mathrm{F} 1$ and $\mathrm{B} 1$ primers were used to detect $\operatorname{cag} \mathrm{A}^{(31)}$.

All PCR mixtures were prepared in a volume of $25 \mu \mathrm{l}$ containing $0.5 \mathrm{n} M$ of each primer; 1 X PCR buffer; $1.5 \mathrm{n} M$ $\mathrm{MgCl}_{2}$; sterilized water, $0.2 \mathrm{n} M$ deoxynucleoside; $1.25 \mathrm{u}$ Taq DNA polymerase, and $2 \mu \mathrm{DNA}$ sample. The mixtures were placed in a thermal cycler.

PCR amplification was performed under the following conditions: initial denaturation at $95^{\circ} \mathrm{C}$ for 2 min followed by 35 cycles of denaturation at $95^{\circ} \mathrm{C}$ for $1 \mathrm{~min}$, annealing and extension for $1 \mathrm{~min}$, and final extension at $72^{\circ} \mathrm{C}$ for $10 \mathrm{~min}$. Annealing temperatures were set at $58^{\circ} \mathrm{C}$ for primers VA3-F/ VA3-R, VA4-F/VA4-R, F1/B1, and at $63^{\circ} \mathrm{C}$ for SS1-F, SS3-F, SS2-F/ VA1-R. Negative and positive controls were used in all reactions. PCR products were visualized by electrophoresis in $2 \%$ agarose gel, stained with ethidium bromide, and examined under UV illumination.

\section{Detection of polymorphism in the IL-8 gene}

Polymorphisms of the IL-8 (-251) gene were characterized using the PCR-restriction fragment length polymorphism (PCR- 
RFLP) method. The volume for the PCR was $25 \mu \mathrm{L}$, containing $0.5 \mathrm{mM}$ of each primer, $1 \mathrm{X}$ PCR buffer, $1.5 \mathrm{mM}$ of $\mathrm{MgCl}_{2}, 0,2$ $\mathrm{mM}$ of each nitrogenated base, $1.25 \mathrm{U}$ of Taq DNA polymerase, $50 \mathrm{ng}$ of DNA and sterile water. The forward and reverse primers for PCR were: 5'-TTCTAACACCTGCCACTCTAG-3' and 5'-CTGAAGCTCCACAATTTGGTG-3', respectively.

The PCR products were digested with $\mathrm{MfeI}$, overnight at $37^{\circ} \mathrm{C}$ and separated by electrophoresis in $2 \%$ agarose gel stained with ethidium bromide. The homozygote genotype for allele $\mathrm{T}(\mathrm{T} / \mathrm{T})$ generated a product of $108 \mathrm{pb}$. The A/A genotype generates a product with two bands ( 76 and $32 \mathrm{pb}$ ). The heterozygous genotype (A/T) presented three bands (108, 76 and $32 \mathrm{pb}$ ). Later on, patients carrying the $\mathrm{A} / \mathrm{T}$ allele were confirmed through DNA sequencing.

PCR products were submitted to direct sequencing in both directions using reagents from the Big Dye Terminator kit (version 3.1, Applied Biosystems, USA) and analysed in the ABI 3730 automatic sequencer (Applied Biosystems, USA). The sequences obtained were edited using the SEQUENCER programme, and aligned with the BIOEDIT programme.

\section{Histological evaluation}

The biopsy specimens were fixed in 10\% buffered formalin solution, embedded in paraffin, cut into sequential $0.4-\mu \mathrm{m}$ sections, and stained with hematoxylin and eosin. Histopathological parameters were graded from 0-3 using the criteria described in the updated Sydney classification system ${ }^{(13)}$ for analysing chronic inflammation, polymorphonuclear activity and intestinal metaplasia.

\section{Statistical analysis}

The Hardy-Weinberg equilibrium of the IL- 8 gene allele was assessed using chi-square tests. Haplotype frequencies were estimated using Arlequin software ${ }^{(27)}$.

The chi-square tests and $\mathrm{G}$ test were utilised for comparing the variables for sex, age, cagA status, $H$. pylori and genotype frequencies between patients and control. The risks of carriers of the different alleles developing adenogastric carcinoma were calculated with the odds ratio. The data were analysed using Bioestat version 5.0 software ${ }^{(4)}$. Differences were considered statistically significant for $P$ values less than 0.05 .

\section{RESULTS}

\section{Epidemiological data}

Table 1 shows comparisons between the frequency of sexes, age group and infection by $H$. pylori between the two groups studied. The patients presented an average age of 58 years, with ages ranging from 20 to 90 years. As for the control group, it presented an average age equal to 36 years, with ages ranging from 18 to 81 years. Patients with adenogastric carcinoma presented higher ages than those of the control group.

Based on the serological research carried out on the two groups, we observed a greater frequency in the presence of $\mathrm{IgG}$ anti- $H$. pylori and anti-cagA antibodies in patients with gastric adenocarcinoma than in the control group (Table 1).
TABLE 1. Epidemiological characteristics of the control group and patients

\begin{tabular}{lccc}
\hline Demographic data & $\begin{array}{c}\text { Control } \\
\mathbf{n}=103\end{array}$ & $\begin{array}{c}\text { Stomach } \\
\text { cancer } \\
\mathbf{n}=102\end{array}$ & $\mathbf{P}$ \\
\hline Age (yr) & 72 & 20 & $<0.001$ \\
$<50$ & 31 & 82 & \\
$>50$ & & & \\
Sex & 59 & 65 & 0.423 \\
Male & 44 & 37 & \\
Female & & & \\
IgG-anti H. pylori & 61 & 101 & \\
Positive & 42 & 1 & 0.001 \\
Negative & & & \\
IgG anti cagA (HP+) & 34 & 74 & \\
Positive & 27 & 27 & \\
Negative & & & \\
\hline
\end{tabular}

Test: control vs stomach cancer

\section{Genotyping of $\boldsymbol{H}$. pylori vacA and cagA genes}

In all patients with gastric adenocarcinoma who were positive on serologic IgG $H$. pylori specific, it was possible to isolate DNA from $H$. pylori in gastric biopsies. In characterizing the vacA alleles of bacterial strains we observed that all of the isolated strains presented the $v a c \mathrm{~A}$ gene. Of all patients analysed, 97\% (98/101) were colonized by only one strain, which contained only one vacA genotype $(\mathrm{s} 1 / \mathrm{m} 1$ or $s 1 / \mathrm{m} 2$ or $s 2 m 2)$ and $3 \%(3 / 101)$ presented infection by more than one strain, with detection of more than one vacA genotype $(\mathrm{s} 1 / \mathrm{m} 1$ and $\mathrm{s} 2 / \mathrm{m} 2)$.

Among patients with monoinfection, 88\% (86/98) contained the $m 1$ allele and $12 \%(12 / 98)$ the $m 2$ allele. With regard to the vac A gene signal sequence region we observed that $96 \%$ (94/98) presented the $s 1$ allele, of those $96 \%$ (90/94) were of the $s l b$ variable and $4 \%(4 / 94)$ of the $s l a$ variable. The $s 2$ allele was observed in 4\% (4/98) of the patients.

Three combinations of the different alleles in the signal and median sequence region were identified $(\mathrm{s} 1 / \mathrm{m} 1, \mathrm{~s} 1 / \mathrm{m} 2$, $s 2 / m 2)$. In patients with monoinfection $4 \%(4 / 98)$ of the bacterial strains observed had the slalml genotype; $84 \%$ $(82 / 98)$ the $s 1 \mathrm{~b} / \mathrm{ml}$ genotype, $8 \%(8 / 98)$ the $s 1 \mathrm{~b} / \mathrm{m} 2$ genotype and $4 \%(4 / 98)$ possessed the $s 2 / m 2$ genotype.

As for the cagA gene, it was detected in 73\% (74/101) of patients infected by $H$. pylori. The presence of the $\operatorname{cagA}$ gene was demonstrated as associated with the presence of the $s 1 \mathrm{~b} / \mathrm{ml}$ genotype of the vacA gene (Table 2).

In the three patients who presented infection by multiple strains, we observed the following genotypes: $s 1$ alm $1-s 2 / \mathrm{m} 2$ cagA+, s1b/m1-s2/m2 cagA+ and s1alm1-s2/m2 cagA (Table 2).

\section{Polymorphism in the IL-8 gene}

Table 3 demonstrates the distribution of the IL-8 -251 genotypes. In both the control group $(P=0.811)$ and patients with adenocarcinoma $(P=0.791)$ the polymorphism studied was in the Hardy-Weinberg equilibrium. Comparing the 
TABLE 2. Genotyping of $H$. pylori strains isolated from patients with gastric adenocarcinoma

\begin{tabular}{lccc}
\hline \multirow{2}{*}{ vacA Genotype } & \multicolumn{2}{c}{ Genotype cagA } & \multirow{2}{*}{ Total (\%) } \\
\cline { 2 - 3 } Monoinfection & Positive (\%) & Negative (\%) & \\
s1a-m1 & 1 & 3 & 4 \\
$s 1 b-m 1$ & 68 & 14 & 82 \\
$s 1 b-m 2$ & 3 & 5 & 8 \\
$s 2-m 2$ & - & 4 & 4 \\
Multiple infection & & & \\
$s 1 a-m 1 / s 2-m 2$ & 1 & 1 & 2 \\
$s 1 b-m 1 / s 2-m 2$ & 1 & - & 1 \\
Total & 74 & 27 & 101 \\
\hline
\end{tabular}

Monoinfection: $\operatorname{vac} \mathrm{A} \times \operatorname{cag} \mathrm{A} \mathrm{G}$ $=18.9493, P=0.0020$

TABLE 3. Frequency of the IL-8 (-251) genotype in the control group and in patients with gastric adenocarcinoma

\begin{tabular}{lcccc}
\hline Genotypes & Control & Patients & OR (IC 95\%) & $P$-value \\
\hline T/T & 42 & 21 & - & \\
A/T & 42 & 56 & $2.66(1.37-5.15)$ & 0.005 \\
A/A & 19 & 25 & $2.63(1.17-5.82)$ & 0.026 \\
Carriers of A & 61 & 81 & $2.65(1.42-4.93)$ & 0.002
\end{tabular}

frequencies of genotypes for the IL-8 (-251) gene, we observed that the patients with gastric adenocarcinoma differed from those in the control group, presenting an increase in the frequency of AA and AT genotypes (Table 3).

\section{Effects of the IL-8(-251) polymorphism, cagA status and vacA gene polymorphism on histological degree of gastritis in noncancerous gastric mucosa adjacent to cancer}

By simultaneously comparing the different types of isolated bacterial strains with the IL-8 (-251) and the histopathological data we observed that carriers of the A allele (AT and AA) infected by virulent strains ( $m 1 s 1 \mathrm{cag} \mathrm{A}+)$ demonstrated a greater risk of presenting a degree of inflammation $(\mathrm{OR}=$ 24.75 IC 95\% 2.29-267.20 $P=0.004)$ and increased neutrophilic activity $(\mathrm{OR}=28.71 \mathrm{IC} 95 \% 2.62-314 P=0.002)$ in the gastric mucosa (Table 4). In that analysis we excluded patients who presented infection with multiple strains (1 AA and 2 TT) and the one patient who did not present infection by $H$. pylori had the IL-8 (-251) A/T genotype.
DISCUSSION

This study was developed in order to increase knowledge regarding factors such as the type of infecting bacterial strain and polymorphism in the IL-8 (-251) gene in gastric carcinogenesis in Pará state.

In comparing the group of patients with gastric adenocarcinoma and the control group we observed that the patients presented greater age on average. Several studies have also described an average age of more than 52 years for development of stomach cancer, considering that it is a multifactor process resulting from exposure to endogenous and exogenous factors. Furthermore, an infection by $H$. pylori determines the occurrence of a chronic inflammation of the gastric mucosa that can persist for decades, in a multiple-stage process that is usually sequential and confers an increased risk for developing stomach cancer over a period of many years ${ }^{(17,28)}$.

In this study the vacA alleles and the presence of the $\operatorname{cag} \mathrm{A}$ gene were characterized in patients with stomach cancer. It was observed that the predominant genotype in the isolated $H$. pylori strains was $s 1 \mathrm{~b} / \mathrm{ml} / \mathrm{cagA}$ positive. Other studies carried out in Brazil have also observed that association ${ }^{(7,22,30)}$.

Colonization of the gastric mucosa by slmlcagA positive strains of $H$. pylori is associated with a more intense inflammatory response and greater levels of damage to DNA in epithelial cells. Inadequate repair of DNA lesions in cells may lead to mutations and genomic instability, constituting the initial stage of the carcinogenesis process ${ }^{(26,30)}$.

Besides the presence of the virulent strain, factors in the host, such as polymorphism in the IL-8 gene have also been studied as a possible factor that influences development of stomach cancer ${ }^{(25)}$. IL-8 is a potent chemotactic factor and an activator of polimorphonuclear leukocytes and macrophages, contributing to an inflammatory response ${ }^{(15)}$. The neutrophils induced by IL-8 synthesis activate radicals such as nitrous oxide that present a mutagenic potential, and thus may cause mutations in the gastric epithelial cells ${ }^{(15,17)}$.

Some studies have demonstrated that patients infected by bacterial strains that possess a cag pathogenicity island present high levels of IL-8 in the stomach tissue, and thus a more intense local inflammatory response $\mathrm{e}^{(6,19)}$.

Furthermore, polymorphism in the IL-8 $(-251)$ has been associated to the increased expression of IL- ${ }^{(21)}$. Several papers have demonstrated an association between IL-8

TABLE 4. Combined effect of IL-8 (-251) polymorphism and bacterial virulence factors (vacA e cagA) on alteration of the gastric mucosa

\begin{tabular}{|c|c|c|c|c|c|c|c|c|c|}
\hline \multirow{2}{*}{ IL-8 } & \multirow{2}{*}{$\begin{array}{l}\text { Strains } \\
\text { H. pylori }\end{array}$} & \multicolumn{2}{|r|}{ GI } & \multirow{2}{*}{ OR (95\% IC) } & \multirow{2}{*}{$P$} & \multicolumn{2}{|r|}{ NA } & \multirow{2}{*}{$\begin{array}{c}\text { OR } \\
(95 \% \text { IC) }\end{array}$} & \multirow{2}{*}{$P$} \\
\hline & & 1 & 2 and 3 & & & 1 & 2 and 3 & & \\
\hline TT & $\mathrm{NV}$ & 3 & 1 & - & - & 3 & 1 & - & - \\
\hline TT & $\mathrm{V}$ & 6 & 9 & $4.5(0.5-3.04)$ & 0.49 & 5 & 10 & $6.03(0.26-45.02)$ & 0.73 \\
\hline Carrier A & NV & 1 & 4 & $12.07(0.69-3.63)$ & 0.33 & 1 & 4 & $12.07(0.3-1.4)$ & 0.57 \\
\hline Carrier A & $\mathrm{V}$ & 8 & 66 & $24.75(2.29-267.20)$ & 0.01 & 7 & 67 & $28.71(2.62-314)$ & 0.002 \\
\hline
\end{tabular}

$\mathrm{GI}=$ Degree of inflammation $(1=$ low 2 and $3=$ moderate to high $), \mathrm{NA}=$ Neutrophilic activity $(1=$ low; 2 and $3=$ moderate to high $)$

$\mathrm{NV}=$ non-virulent $\operatorname{strain}(s 2 \mathrm{~m} 2$ cag A negative e $s 1 \mathrm{~m} 2$ cag A negative)

$\mathrm{V}=$ virulent strains $(s 1 m 1 c a g \mathrm{~A}+, s 1 m 2 c a g \mathrm{~A}+, s 1 m 1 c a g \mathrm{~A}$ negative $)$ 
(-251) polymorphism and an increased risk of developing gastroduodenal diseases ${ }^{(21,25,30)}$.

In our study, we observed a greater frequency in the AT and AA allele genotypes among patients with adenocarcinoma than in the control group, with the presence of allele $\mathrm{A}$ being associated with the risk of developing gastric adenocarcinoma. Regarding the histopathological data, we observed that patients with genotypes AA and AT presented higher levels of inflammation and neutrophilic activity than carriers of genotype TT.

The presence of the A allele in the -251 position of the IL- 8 gene was associated with an increase in the risk of stomach cancer in Japanese, Korean, Chinese and Iranian populations ${ }^{21}$ 25, 29, 33). Additionally, some studies have demonstrated that patients carrying the A allele present higher production of IL-8, leading to alteration in the quality and intensity of inflammatory responses produced by the host after exposure to H. pylori ${ }^{(29,33)}$.

Our data indicate that the interaction between polymorphism in the IL-8 (-251) gene, particularly with carriers of the A allele and the infecting type of $H$. pylori strain $(\operatorname{sim} 1 \operatorname{cag} \mathrm{A}$ positive) performs an important function in development of gastric adenocarcinoma.

Vinagre RMDF, Corvelo TCO, Arnaud VC, Leite ACK, Barile KAS, Martins LC. Determinação das cepas do Helicobacter pylori e do polimorfismo do gene da interleucina-8 em pacientes com câncer gástrico. Arq Gastroenterol. 2011;48(1):46-51.

RESUMO - Contexto - A neoplasia gástrica é a segunda causa mais comum de morte por câncer no mundo e o $H$. pylori é classificado como carcinógeno humano tipo I pela Organização Mundial de Saúde. Entretanto, apesar da elevada prevalência da infecção pelo H. pylori em todo mundo, menos de $3 \%$ de indivíduos portadores dessa bactéria desenvolvem neoplasias gástricas. Tal fato indica que a evolução para malignização possa estar associada a fatores bacterianos, do hospedeiro e do ambiente. Objetivos - Investigou-se a associação do polimorfismo da região promotora do gene IL-8 (-251) e do genótipo do H. pylori, baseado nos alelos vacA e na presença do gene cagA, com a clínica e os dados histopatológicos. Métodos - Em estudo prospectivo, 102 pacientes com câncer gástrico e 103 voluntários saudáveis foram analisados. O polimorfismo da IL-8 (-251) foi determinado pela reação de PCR-RFLP e sequenciamento. Para genotipagem dos alelos vac $A$ e do gene cagA das cepas bacterianas foi utilizada a PCR. As biopsias gástricas foram avaliadas histologicamente. Resultados - A sorologia para o H. pylori foi positiva em 101 (99\%) de todos os pacientes analisados, e 98 (97\%) deles foram colonizados por apenas uma cepa bacteriana. Em pacientes com monoinfecção, 82 (84\%) das cepas bacterianas observadas apresentavam o genótipo $\mathrm{s} 1 \mathrm{~b} / \mathrm{ml}$. O gene cagA foi detectado em $74(73 \%)$ dos pacientes infectados pelo $H$. pylori. A presença do gene cagA demonstrou estar associada com a presença do genótipo $\mathrm{s} 1 \mathrm{~b} / \mathrm{ml}$ do gene vacA $(P=0,002)$. Quanto ao polimorfismo do gene da IL-8 $(-251)$, observou-se que os genótipos AA $(P=0,026)$ e AT $(P=0,005)$ foram mais frequentes no grupo de pacientes com adenocarcinoma gástrico. Comparando os diferentes tipos de cepas bacterianas isoladas, com o polimorfismo do gene da IL-8-251 e dados histopatológicos, observou-se que, portadores do alelo A (AT e AA) infectados por cepas virulentas ( $m 1 s 1 \mathrm{cagA}+)$, demonstraram risco aumentado de apresentar maior grau de inflamação (OR = 24,75 IC 95\% 2,29-267,20 $P=0,004)$ e aumento da atividade neutrofílica (OR = 28,71 IC 95\% 2.62-314 P = 0,002) na mucosa gástrica. Conclusão - Os resultados demonstram que a interação entre o polimorfismo do gene da IL-8, particularmente em portadores do alelo A, e o tipo de cepa infectante do $H$. pylori ( $1 m 1$ cagA positiva) desempenha importante função no desenvolvimento do câncer gástrico.

DESCRITORES - Helicobacter pylori. Neoplasias gástricas. Polimorfismo, genético. Interleucina-8.

\section{REFERENCES}

1. Ashour AA, Magalhães PP, Mendes EN, Collares GB, de Gusmão VR, Queiroz DM, Nogueira AM, Rocha GA, de Oliveira CA. Distribution of vacA genotypes in Helicobacter pylori strains isolated from Brazilian adult patients with gastritis, duodenal ulcer or gastric carcinoma. FEMS Immunol Med Microbiol. 2002;33:173-8.

2. Atherton JC. The clinical relevance of strain types of Helicobacter pylori. Gut. 1997;40:701-3

3. Atherton JC, Peek RM Jr, Tham KT, Cover TL, Blaser MJ. Clinical and pathological importance of heterogeneity in vacA the vacuolating cytotoxin gene of Helicobacter pylori. Gastroenterology. 1997;112:92-9.

4. Ayres M, Ayres MJ, Ayres DL, Santos AS. Bioestat 4.0. Aplicações estatísticas nas áreas das ciências biológicas e médicas. 3rd ed. Belém, PA: Sociedade Civil Mamirauá MCT; 2005. p.291, 364.

5. Batista dos Santos SE, Rodrigues JD, Ribeiro-dos-Santos AK, Zago MA Differential contribuition of indigenous men and women to the formation of an urban population in the Amazon region as revealed by mtDNA and Y-DNA. Am J Phys Anthropol. 1999;109:175-80.

6. Beswick EJ, Bland DA, Suarez G, Barrera CA, Fan X, Reyes, VE. Helicobacter pylori binds to CD74 on gastric epithelial cells and stimulates interleukin-8 production. Infect Immun. 2005;73:2736-43.

7. Brito CA, Silva LM, Jucá N, Leal NC, de Souza W, Queiroz D, Cordeiro F, Silva NL. Prevalence of $c a g \mathrm{~A}$ and $v a c \mathrm{~A}$ genes in isolates from patients with Helicobacter pylori-associated gastroduodenal diseases in Recife, Pernambuco, Brazil. Mem Inst Oswaldo Cruz. 2003;98:817-21
8. César AC, Silva AE, Tajara EH. [Genetics and environmental factors in gastric carcinogenesis]. Arq Gastroenterol. 2002;39:253-9.

9. Choi IJ, Fujimoto S, Yamauchi K, Graham DY, Yamaoka Y. Helicobacter pylor environmental interactions: effect of acid conditions on $H$. pylori induced gastric mucosal interleukin-8 production. Cell Microbiol. 2007;9:2457-69.

10. Correa P. Helicobacter pylori and gastric carcinogenesis. Am J Surg Pathol. 1995; 19:537-43.

11. Cover TL, Tummuru MK, Cao P, Thompson SA, Blaser MJ Divergence of genetic dequences for the vacuolating cytotoxin among Helicobacter pylori strains. J Biol Chem. 1994;269:10566-73.

12. Crabtree JE, Lindley LJ. Mucosal interleukin-8 and Helicobacter pylori-associated gastroduodenal disease. Eur J Gastroenterol Hepatol. 1994;6:s33-8.

13. Dixon MF, Genta RM, Yardley JH, Correa P. Histological classification of gastritis and Helicobacter pylori infection: an agreement at last? The International Workshop on the Histopathology of Gastritis. Helicobacter. 1997;1(Suppl):S17-24.

14. Dunn BE, Cohen, Blaser MJ. Helicobacter pylori. Clin Microbiol Rev. 1997;10:720-41.

15. Go MF, Crowe SE. Virulence and pathogenicity of Helicobacter pylori. Gastroenterol Clin North Am. 2000;29:649-70.

16. Hammar PW, Tyszkiewicz T, Wadström T, O’Toole PW. Rapid detection of Helicobacter pylori in gastric biopsy material by polymerase chain reaction. J Clin Microbiol. 1992;30:54-8.

17. Israel DA, Peek RM. Pathogenesis of Helicobacter pylori-induced gastric inflammation [review article]. Aliment Pharmacol Ther. 2001;15:1271-90.

18. Kamali-Sarvestani E, Bazargani A, Masoudian M, Lankarani K, Taghavi A, Saberifiroozi M. Association of $H$. pylori and vacA genotypes and IL-8 gene polymorphisms with clinical outcome of infection in Iranian patients with gastrointestinal diseases. World J Gastroenterol. 2006;12:5205-10. 
19. Keates S, Keates AC, Warny M, Peek RM Jr, Murray PG, Kelly CP. Differential activation of mitagen-activated protein kinases in AGS gastric epithelial cellsby cag+ and cag- Helicobacter pylori. J Immunol. 1999;163:5552-9.

20. Kusters JG, van Vliet AH, Kuipers EJ. Pathogenesis of Helicobacter pylori infection. Clin Microbiol Rev. 2006;19:449-90.

21. Lu W, Pan K, Zhang L, Lin D, Miao X, You W. Genetic polymorphisms of interleukin (IL)-1B, IL-1RN, IL-8, IL-10 and tumor necrosis factor \{alpha\} and a risk of gastric cancer in a Chinese population. Carcinogenesis. 2005;26: 631-6.

22. Martins LC, Corvelo TC, Demachki S, Araujo MT, Assumpção MB, Vilar SC, Freitas FB, Barbosa HP, Fecury AA, do Amaral RK, Dos Santos SE. Clinical and pathological importance of vacA allele heterogeneity and cagA status in peptic ulcer disease in patients from North Brazil. Mem Inst Oswaldo Cruz. 2005;100:875-81.

23. Melo Barbosa HP, Martins LC, Dos Santos SE, Demachki S, Assumpção MB, Aragão CD, de Oliveira Corvelo TC. Interleukin-1 and TNF-alpha polymorphisms and Helicobacter pylori in a Brazilian Amazon population. World J Gastroenterol. 2009; 15:1465-71.

24. Nogueira C, Figueiredo C, Carneiro F, Gomes AT, Barreira R, Figueira P, Salgado C, Belo L, Peixoto A, Bravo JC, Bravo LE, Realpe JL, Plaisier AP, Quint WG Ruiz B, Correa P, van Doorn LJ. Helicobacter pylori genotypes may determine gastric histopathology. Am J Pathol. 2001;158:647-54.

25. Ohyauchi M, Imatani A, Yanechi M, Asano N, Miura A, Lijima K, Koike T, Sekine H, Ohara S, Shimosegawa T. The polymorphism interleukin 8-251 A/T influences the susceptibility of Helicobacter pylori related gastric diseases in the Japanese population. Gut. 2005;54:330-5.
26. Salama NR, Otto G, Tompkins L, Falkow S. Vacuolating cytotoxin of Helicobacter pylori plays a role during colonization in a mouse model of infection. Infect Immun. 2001;69:730-6.

27. Schneider S, Roessli D, Excoffier L. Arlequin Ver 2.0: A software for population genetics data analysis. Geneva, Switzerland: Genetics and Biometry Lab, Department of Anthropology, University of Geneva; 2000.

28. Suerbaum S, Michetti P. Helicobacter pylori infection. N Engl J Med. 2002;347:117586.

29. Taguchi A, Ohmiya N, Shira K, Mabuchi N, Itoh A, Hirooka Y, Niwa Y, Goto $\mathrm{H}$. Interleukin-8 polymorphism increases the risk of atrophic gastritis and gastric cancer in Japan. Cancer Epidemiol Biomarkers Prev. 2005;14:2487-93.

30. Thomazini CM, Pinheiro NA, Pardini MI, Naresse LE, Rodrigues MAM Helicobacter pylori and gastric cancer: distribution of cagA and vacA genotypes in patients with gastric carcinoma. J Bras Patol Med Lab. 2006;42:25-30.

31. Tummuru MK, Cover TL, Blaser MJ. Cloning and expression of a high-molecularmass major antigen of Helicobacter pylori: evidence of linkage to cytotoxin production. Infect Immun. 1993;61:1799-809.

32. Van Doorn LJ, Figueiredo C, Mégraud F, Pena S, Midolo P, Queiroz DM, Carneiro F, Vanderborght B, Pegado MD, Sanna R, De Boer W, Schneeberger PM, Correa P, Ng EK, Atherton J, Blaser MJ, Quint WG. Geographic distribution of vacA allelic types of Helicobacter pylori. Gastroenterology. 1999;116:923-30.

33. Ye BD, Kim SG, Park JH, Kim JS, Jung HC, Song IS. The interleukin-8-251 A allele is associated with increased risk of noncardia gastric adenocarcinoma in Helicobacter pylori-infected Koreans. J Clin Gastroenterol. 2009;43:233-9.

Received 16/8/2010 Accepted 15/10/2010 